\title{
COMMUNICATING TRUSTS
}

\author{
Johana Alexandra Nino Rodriguez \\ and Marianne Cherrington
}

\section{PREAMBLE}

Trusts are legally binding arrangements that transfer legal ownership of assets for beneficiaries. For the first time in over seventy years, reform has arrived, via the Trusts Act 2019 ('the Act'), which came into effect on 30 January 2021. The Act significantly changes trust law and communication underpins the changes. This research stems from a work-based learning project within an Auckland law firm, where the processes for communicating the Act's implications and variations were investigated. Stakeholder messaging became the unifying purpose for the research, beyond the need to understand the key effects of new statutory requirements. This paper summarises the key takeaways from the work-based industry project in terms of communicating trusts. Secondary research, semi-interview and observational methods established the Act's implications, as well as issues leading to key findings in terms of messaging and communication to build brand association and loyalty. The novel contribution of this research, realised in this paper, is the extension of the research via the use of coresearching partnerships to design a framework around the stakeholder communication network requirements for law firms as they implement a new Trusts Act regime for new and existing clients.

\section{INTRODUCTION}

Trusts are meant to protect assets for beneficiaries. In New Zealand, trusts have been criticised as tax loopholes for trustees that are inaccessible to stakeholders, especially beneficiaries (Law Commission, 2002). The Trusts Act 2019 is meant to encourage disclosure and discussion around trusts so that wealth is not hidden from beneficiaries, rather it informs beneficiaries and allows those involved in trusts to be aware and involved in financial affairs relating to trusts (Kenny \& Speight, 2020). In this paper, the notion of representing and unravelling the 'voice' of beneficiaries is examined via a work-based learning project in a professional practice. Opportunities to communicate are thoughtfully applied in the context of the new Trusts Act 2019.

In the environment of work-based learning, asset accumulation and protection are apt. For all workers, thought for the future with strong foundations for the next generation must be discussed and learned; trusts are a common means of safeguarding wealth, accrued over one's working life, for benefit of those we care about.

In the context of pandemic uncertainty and apprehension, legal firms are pivoting their organisational strategy; principals are reassessing professional plans. There is a need to create opportunity from a safe, secure foundation. This usually requires asset reallocation. The new Trusts Act 2019 (the Act) came into effect in 2021, compelling trustees and settlors to reassess existing trusts and how they operate, with new obligations. Significant changes to trust law profit from discussion with experts and stakeholders, predominantly in the context of family trusts and estate planning and including winding up of existing trusts (McLeod, 2020a). 
A critical component of this project was to assess implications of the new Act. Secondary research was undertaken under the direction of the principals of the law firm in which the project was undertaken. Following, interviews were undertaken with key members of the law firm to understand better how trusts were applied in practice, and to understand better the benefits and misuses of trusts from the viewpoint of a lawyer. In addition, key findings from the interviews concerned transformational change as well as possibilities to build and maintain client loyalty. Observational research methodologies established issues that related to implementation of the Act; these included process and systems barriers within the firm. The key findings from observational methods related to trust documentation, corporative trustee governance, and trustee power. For example, trustees must confirm that they can comply with all new trustee obligations and duties set out in the trust deed under the Act, which provides default administrative rules, mechanisms to resolve trust-related disputes, and makes the law of trusts more accessible (Speakman Law, 2020). Law firms must be proactive to avoid major risk from the loss of family trusts. Communication processes throughout the adoption of a preventive risk management action plan were key in avoiding such risk.

In particular, discussions concerning trust resettlement support alignment with the new Act. Trust resettlement occurs when a family trust completely restates the express terms of the trust deed, incurring potential tax consequences, as well as in changes in the rights and obligations of the parties (McLay, 2020). This has longterm consequence in terms of wealth creation for future generations. Trust resettlement is one of the biggest challenges for trustees nowadays because it can be done depending on the existing structure of each trust property. Internal system updates will be required at law firms in order to deliver trust file information for those involved. As well, the risk management process must be assessed, as a key to delivering practical preventative law for trust resettlement. Masterful communications can be transformational tools in preventative services, minimising negative implications while maintaining and building brand and client loyalty (Zaffron \& Logan, 20II).

\section{TRUSTS ACT 2019}

The Trustee Act of 1956 was originally meant to ensure family trust funds were cheaper and simpler to create (Hawes, 2012); it became dated, ill-managed and poorly constituted. Inconsistencies resulted in legal action.

The purpose of the Trusts Act 2019 is to reform trust law (Ministry of Justice, 2020) by:

- enforcing reform of New Zealand trust law through restatement of the law,

- making the law of trusts more accessible, and

- providing rules to improve family trust administration in the future.

The changes create implications such as winding up of family trust deeds and new obligations for trustees. For this reason, it is vital to reassess if existing trusts are fit for purpose or if variations are needed. Trustees and settlors must re-evaluate their roles and responsibilities. Therefore, trustees must understand key changes in order to deal with these new responsibilities for all existing and future trust funds in New Zealand.

One implication is that the trustees need to understand their new fundamental administrative obligations within the terms of the trust deed, and a second implication is the inevitable winding-up of some family trusts. Tax implications of trust resettlement will be a challenge for trustees. This project looked at practical preventive law for trust resettlement in order to minimise future risk, while building and maintaining client loyalty. Risk management assessment processes were examined, to identify implications of upcoming changes at a law firm. Law firms must fundamentally appreciate their client relationships and update internal systems for trusts, as part of an overall risk management process for the delivery of practical preventative law for Trust resettlement. 


\section{TRUSTS INFORMATION CATEGORIES}

This work-based learning project examined secondary research, reported in an extensive industry project report. The research was augmented with interviews and observational research methods, which were used to identify information categories or blocks for Trusts information within the law firm. From this primary research, key themes were extracted from data collected in context. Group blocks are depicted in Figure I.

Trust Documentation is a key consideration in the Trusts Act 2019 as a mandatory duty concerning record keeping, holding and availability of core trust documents (Costa \& Frankema, 2007); it may not be modified nor excluded by the terms of the trust. It means trust documentation matters to build a relationship between trustees and the trust because the terms of the trust are defined in the trusteeship (Walker \& Shahbaz, 2020). This is a communicative issue. The trust file in internal systems with a compulsory hard copy is an elemental duty for trustees, and in resettling and re-evaluating internal systems (Kemps Weir, 2020). Additionally, the Trusts Act mitigates the gap between the income tax rate and the trust rate. Trust documentation increases the power to exploit the trust system as trusts not only safeguard assets, they favour the dodging of tax obligations (Coughlan, 2020).

Figure I. Group blocks of information regarding trusts information in a particular law firm.

Trust Documents
- Mandatory
duties.
$\checkmark$ Build a
relationship
between trustees
and trust.
Trust Documents
Opening gap
between the
income tax rate
and the trust
rate create.
$\checkmark$ Avoid dodging
tax obligations.
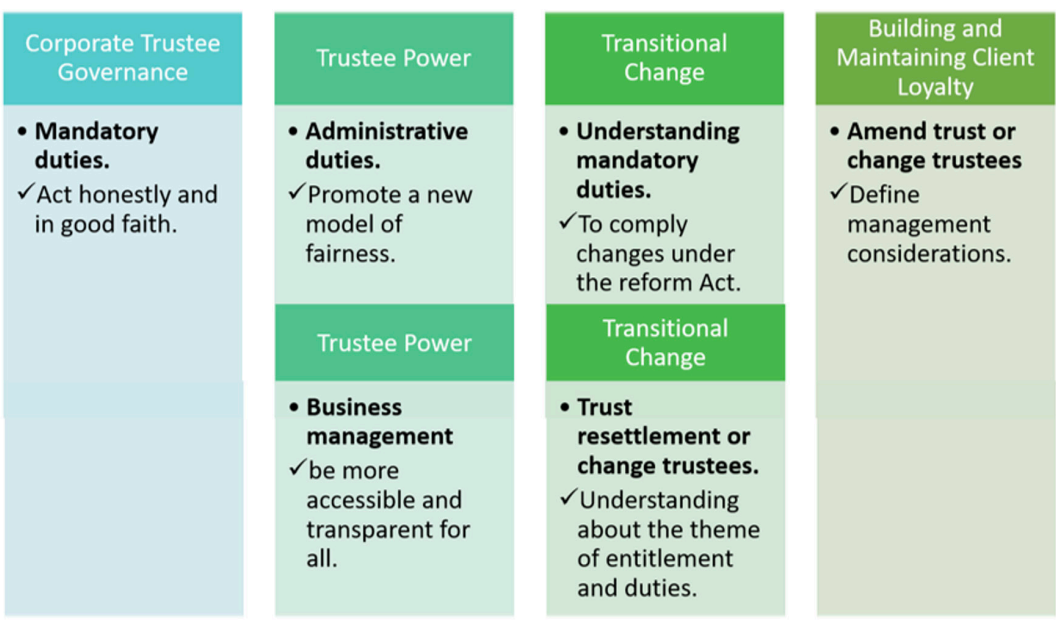

Trust documentation went through a three-stage process in the law firm. Firstly, the main information from the trust file was transcribed into a computerised format. The second stage was to complete a checklist sheet using a confirmation template to update client trust files in both record-holding information formats. The final stage was to create a data-entry form using a set of macros interlinked with the client sheet, containing core trust information in order to facilitate access to information effectively. The process is of huge importance in trust documentation, favouring effective facilitative access to information (Quill, 2020). It is straightforward to ease trust file updates for trustees, beneficiaries, resolution, or other documents. Under the Trusts Act 2019, firms have mandatory duties regarding recording core trust information; penalties can be imposed otherwise.

Trustee power is key issue within the new Trusts Act 2019. It is associated with administrative duties having many implications (NZLAW, 2020). A trust may accumulate income to the extent that it is consistent with its terms (Parliamentary Counsel Office, 2019). A new model of fairness can be promoted with trust deeds that are restated, modified, or removed to minimise harm made by presumption or sham trusts, as when a trustee makes all decisions without the consent or benefit for all parties (Ammundsen, 2020); in that case, the new legislation will be more useful, with more flexibility in the default provisions (Parliamentary Counsel Office, 2019). 
Transitional change is needed for law firms updating their internal systems in favour of establishing their new obligations and duties under the Trusts Act 2019. It takes time to understand and communicate mandatory duties that are fundamental to complying with the wide range of duties and obligations reformed under the Act. The majority of trust deeds will likely need to amend or change trustees (McLeod, 2020b). This means that trustees have more obligations under the regulatory needs of the Act, as well as greater power over trust property management. Existing documents must be reviewed to ensure trusteeship complies with the list of requirements under the Act.

According to interview research, due to changes in the Trusts Act 2019 and tough times in 2020, the law firm wound out 20 per cent of the family trusts. Disinformation and bias negatively affected the trust business. With a more proactive communication strategy, the firm could have reformed of a good proportion of those trusts.

\section{FAMILIES, TRUSTS AND DISCLOSURE}

The simplicity of setting up family trusts years ago without notifying family members, now complicates trusts, as circumstances have changed. Some clients feel intimidated by possible changes in benefactor behaviour because the amount of wealth now accumulated is considerable; transparency is required in the new Act. It has been estimated there could be more than half of trust business lost in New Zealand (Stock, 2020). Many trustees will not fulfil requirements under the Act even if law firms can support their needs. Strategic transitional plans are needed and this must be communicated by law firms to build loyalty and brand image.

A key and important change for all existing and future trusts in New Zealand is the new face of trust law. The Act will provide mechanisms for trust disputes to be resolved outside of the courts, focusing on mediation and alternative dispute resolution (Gibson Sheat, 2019). Some notable changes to existing trust law include:

- an obligation to disclose basic trust information to the beneficiaries of the trust, by right as a beneficiary

- increased mandatory and default duties as trustee obligations; there are new obligations to disclose the existence of a trust and to provide trust information to the beneficiaries (Powell, 2020)

- enhanced trustee record retention requirements

- $\quad$ an ability to delegate duties and powers

- a maximum duration of a trust of 125 years

- clarification of the Court's powers concerning the trust and enabling the use of alternative dispute resolution for trustee/beneficiary disputes, that is dispute resolution

- a simplified process for replacing mentally incapable trustees from land titles, mostly avoiding the need to involve the High Court.

Experts consider that the small reforms made to the Trustee Act 1956 cannot stop fraudulent actions due to a lack of accountability; there are no checks or balances to stop losing financial resources (Bennett, 2018). As trust funds are one of the most flexible asset ownerships, the new Trusts Act 2019 will have more stringent rules for how trusts must operate (McLeod, 2020a). Therefore, New Zealanders who invest in a trust fund as a financial option must also invest in a better future for all beneficiaries (Norton, 2020).

Maintaining and building client loyalty is vital when creating stable client relationships. The majority of trust deeds may need to amend or change trustees because the core trust documents do not define many details about relevant considerations about managing the trust assets and investments (McLeod, 2020a). This opens a gap between beneficiary interest priorities and a correct application of the trust deed terms. Based on the trust deeds drafted, trustees must notify primary beneficiaries about basic trust information to clarify the beneficiary appointed and benefits under the family trust fund (Norton, 2020). Additionally, the duration of trust can be extended from 80 years to 125 years, accelerating internal trust changes only in existing trusts. Some trusts may 
not be well-created for resettlement (Yu, 2002). Family trusts that have a long lifespan must carefully identify any threats against any client's family trust. In other words, the trustees' main job is to protect the accumulated wealth of their clients through a transparent and flexible channel between beneficiaries and the trust in order to minimise interest conflict and potential issues between all parties. This gives a huge importance to an open communication about family trust files.

\section{KEY OPPORTUNITIES FOR COMMUNICATION REGARDING TRUSTS}

The Trusts Act 2019 will reduce trust business for legal firms; it is a real risk to manage. It is also an opportunity to build client trust and brand loyalty (Figure 2). Some key insights from the work-based learning project are:

- Law firms might fail to maintain and build positive relationships with clients if client perceptions or mindsets shift during transitional changes; a firm can influence preventive risk management by helping clients avoid winding family trusts by reframing the Trusts Act 2019 changes as beneficial.

- Clients are likely to benefit from a ready financial viability plan that limits costs and inconveniences involved in transitional change. Firms can temper risk management with a financial strategy that can minimise client risks over time.

- Firms can re-communicate their ethical obligations and duties of care at all levels as a model for their clients (Wang \& Li, 2019); a stronger relational culture can emerge from enhanced compliance to benefit stakeholders (Barclift, 2008).

Firms can use ADKAR (Awareness, Desire, Knowledge, Ability and Reinforcement) change management models to activate communications opportunities by brainstorming stakeholder relationships (see Figure 2).

Figure 2. Law firm communications ADKAR change management opportunities (Pearson, 2019)

\begin{tabular}{|c|c|c|c|c|}
\hline $\begin{array}{l}\text { Phase 1- Notify } \\
\text { stakeholders. }\end{array}$ & $\begin{array}{c}\text { Phase 2- Awareness is a } \\
\text { goal. }\end{array}$ & $\begin{array}{c}\text { Phase } 3 \text { - Change } \\
\text { management strategies } \\
\text { and suitable metrics. }\end{array}$ & $\begin{array}{l}\text { Phase } 4 \text { - The } \\
\text { transformation period. }\end{array}$ & $\begin{array}{c}\text { Phase 5- } \\
\text { Reinforcement. }\end{array}$ \\
\hline $\begin{array}{r}\text { Promote open } \\
\text { communication } \\
\text { about transitional } \\
\text { changes can } \\
\text { increase } \\
\text { engagement } \\
\text { between all parties. } \\
\text { Free flow of } \\
\text { information } \\
\text { between different } \\
\text { parts. } \\
\text { Not highlight } \\
\text { hierarchy. }\end{array}$ & $\begin{array}{r}\text { Increase awareness } \\
\text { and knowledge } \\
\text { might be employed } \\
\text { in response to the } \\
\text { changes that are } \\
\text { occurring or } \\
\text { needed. } \\
\text { Listening to } \\
\text { suggestions, } \\
\text { answering and } \\
\text { asking questions } \\
\text { can foster a positive } \\
\text { relationship } \\
\text { between the client } \\
\text { and the trustee. }\end{array}$ & $\begin{array}{r}\text { Education and } \\
\text { communication can } \\
\text { help the adaptation } \\
\text { of changes easily. } \\
\text { Promote wishes for } \\
\text { change in order to } \\
\text { work as a team and } \\
\text { move forward. } \\
\text { Monitor a set of } \\
\text { parameters until } \\
\text { business outcomes } \\
\text { are achieved. }\end{array}$ & $\begin{array}{r}\text { Work on the three } \\
\text { distinct levels of } \\
\text { change } \\
\text { - Connection. } \\
\text { Improvement. } \\
\text { Transformation. } \\
\text { Overlook all the } \\
\text { implementation } \\
\text { process because of } \\
\text { operating it } \\
\text { correctly and safely. } \\
\text { Motoring } \\
\text { development } \\
\text { identifies gaps in } \\
\text { advance and correct } \\
\text { them on time. }\end{array}$ & $\begin{array}{r}\text { Reinforcement can } \\
\text { ensure change by } \\
\text { using new suitable } \\
\text { metrics over time, } \\
\text { enforcing change } \\
\text { management. } \\
\text { Measuring change } \\
\text { through a scope of } \\
\text { risk management } \\
\text { can reduce future } \\
\text { risks. }\end{array}$ \\
\hline
\end{tabular}




\section{DESIGNING A FRAMEWORK FOR STAKEHOLDER COMMUNICATIONS}

Communication management drives change and adds stakeholder value in organisations. Communications impact organisational culture, productivity, as well as profits. Law firms regularly deal with sensitive matters and good communication can help eliminate a greater range of risks in business.

There is no one-size-fits-all approach to the rich diversity of stakeholders involved in trusts. For trustees, maintaining a good ongoing relationship with stakeholders is relevant because trust files require amendments and legal compliance reviews on a recurring basis (Jayatilleke \& Lai, 20I8). A well-planned approach encourages effective communication management for all stakeholders and not just for those who make the loudest demands (Te Puni Kōkiri, 2007). All main information about trust management should be noted in a holistic stakeholder communication plan in order to avoid misunderstandings. For example, the lack of information about reviewing or amending trust deeds before the Trusts Act 2019 came into effect, brought on relationship splits, partly because of misconception. Therefore, the requirements of the Act, alongside formal, informal and technical communication, enable trusts to work constructively. The requirements set out by trust deeds need the correct contact channel from the client perspective, to prevent issues in trust management.

This holistic communication plan should be client centric, but the Act has a greater focus on beneficiaries as well, returning to the original intent of a family trust, as legally binding arrangements that transfer legal ownership of assets for beneficiaries. Behind that intent should be a desire for improved life quality for those involved in the trust. An interesting and holistic perspective could be developed from Te Ira Tangata framework (Te Puni Kōkiri, 2007). The framework develops Te Ira Tangata (life quality) as an additive equation:

Te Ira Tangata (life quality) = Mātauranga (knowledge) + Whakamana (influence) + Rawa (resources)

Te Ira Tangata (life quality) is what family trusts are all about; the new Act purposes to bring beneficiaries back into the discussion and make trusts more transparent for all stakeholders. The Act implications can fit into the Te Ira Tangata framework to focus key stakeholder communications as in Figure 3.

Figure 3. Trusts Act 2019 key knowledge influence and resource changes for communications planning.

\begin{tabular}{|l|l|l|l|}
\cline { 2 - 4 } \multicolumn{1}{l|}{ Te Ira Tangata } & Mātauranga (knowledge) & Whakamana (influence) & Rawa (resources) \\
\hline trustees & $\begin{array}{l}\text { Duty of care: specialised } \\
\text { knowledge or experience }\end{array}$ & Decide a range of factors & $\begin{array}{l}\text { Selection of information } \\
\text { to provide or withhold }\end{array}$ \\
\hline beneficiaries & $\begin{array}{l}\text { 'basic trust information' } \\
\text { available to beneficiaries }\end{array}$ & $\begin{array}{l}\text { Adult beneficiaries may } \\
\text { unanimously end a trust }\end{array}$ & $\begin{array}{l}\text { Can apply trust property } \\
\text { for beneficiary welfare }\end{array}$ \\
\hline legal advisors & $\begin{array}{l}\text { Legal and trust advice; } \\
\text { financial and tax support }\end{array}$ & Act as a specialist trustee & Wide-ranging paperwork \\
\hline
\end{tabular}

Although Te Ira Tangata is a holistic framework, the $3 \times 3$ depiction given in Figure 3 can be used as a starting point for legal firms to become more relational in their approach to trusts and their clients, as more than just trustees. Firms that have legacy values, that seek to build relationships with clients and for clients, can explore the 'Te Ira Tangata equation' as a synergistic means of creating lasting value and intergenerational wealth and development for all stakeholders linked through the trust structure.

A Te Ira Tangata communications framework for the new implications from the Trusts Act 2019 requires acceptance of the implications under the Act, such as reforms to trust governance, trust documentation, trustee power, transitional change, and maintaining and building client loyalty. Thus, a holistic communication plan is vital to enhance stakeholder confidence and value through a process of open and transparent communication 
in order to meet trust business outcomes under the Act for all stakeholders, including those who are not aware or informed about how much the trust is worth or how beneficiaries gain.

Continuity in relationships with dedicated contact spokespeople supports service and brand loyalty aims. Law firms should look at each trust holistically; trustees and beneficiaries can be united and speak with one voice (Te Puni Kōkiri, 2007). Typically, a spokesperson, such as a partner in the firm or representatives of the firm, can be appointed as spokespeople; they may be any director who is well aware of all levels of the organisation who are trustworthy, relationship builders. Processes that inform and support complex decisions that have major impact on the lives of clients and beneficiaries must include legal representatives who are empathetic, discrete and fair, in order to maintain and build good relationships with stakeholders, and encourage rich and valuable insights between parties. In this way, a comfortable and strong strategic advantage within the firm can be built from generation to generation, in the same way that the Act builds assets inter-generationally.

\section{CONCLUSIONS}

The Trusts Act changes will make trusts more transparent, communicative, inform up-to-date trust practice, and clarify trustee powers, duties, roles and requirements (Cone et al., 2019). While reviewing processes, law firms can uptake opportunities with superlative messaging practices with practical insights to benefit practitioners, settlors and beneficiaries. It will build loyalty and the brand.

As part of a work-based learning project within a law firm, a framework based on Te Ira Tangata is suggested due to its focus on life quality in a New Zealand context; the framework can highlight implications and variations in the Act. Law firms can overcome the loss of trust business by magnifying the opportunity to build intergenerational relationships with trustees and beneficiaries by focusing on the overall intent of trusts and asset benefaction. Te Ira Tangata has a life quality focus that aligns with trusts intent.

The Te Ira Tangata communications framework will require development in the context of evolving trust law. Each law firm will need to communicate trust information more proactively, and the framework has the potential to keep clients with the firm and build relationships into the future with beneficiaries and other stakeholders. Future research in the firm can evolve around this framework and even expand its use as Te Ira Tangata becomes part of the culture of the firm along with the communicative norms that define their brand.

Future work within the law firm can assess and refine the framework, notably in terms of its communications and relational value in a trusts context. The framework is a starting point to hone stakeholder messaging in terms of communicating trusts; it can be used similarly as a framework for similar stakeholder communication processes within organisations. 
Johana Nino is an Applied Management graduate from Otago Polytechnic. She previously completed a Bachelor of Finance and Foreign Trade in Bogota, Colombia. Johana aims to share her research with trustees and people interested in the implications of the new changes to the Trusts Act because her research interests include the financial sector in general and wealth management.

(D) https://orcid.org/0000-0003-4410-2992

Marianne Cherrington is a Principal Lecturer at Otago Polytechnic Auckland International Campus with a focus on sustainability as well as computer science and analytics. A lecturer in disruptive innovation, her research into machine learning feature selection algorithms applies in many fields, producing interesting collaborations with local and international partners in many disciplines and sectors.

Email: Mariannec@op.ac.nz

(10) https://orcid.org/0000-0002-1240-2010

\section{REFERENCES}

Ammundsen, V. (2020, February 26). Trust Series 2020 - Trust Fundamentals. [Original Broadcast] https://register.gotowebinar. com/recording/950649/53656037635

Barclift, Z. (2008). Preventive Law: A Strategy for Internal Corporate Lawyers to Advise Managers of Their Ethical Obligations. Journal of the Legal Profession, 33(3I), Paper 34I. https://open.mitchellhamline.edu/facsch/341

Bennett, L. (2018, May 17). Treaty Negotiations Minister Andrew Little concerned by lack of accountability on Te Arawa River Iwi Trust spending. New Zealand Herald. Retrieved from www.nzherald.co.nz/nz/treaty-negotiations-minister-andrew-littleconcerned-by-lack-of-accountability-on-te-arawa-river-iwi-trust-spending/YB4QCSSOVCB2VXMR5OJI7XNTRY/

Clark, D. (2021, April 16). Speech releasing the Digital Council's report 'Towards Trustworthy and Trusted Automated Decision Making in Aotearoa'. https://www.beehive.govt.nz/speech/speech-releasing-digital-councils-report-towardstrustworthy-and-trusted-automated-decision

Cone, G., Shan, C., \& Barber, S. (2019). A Trusts Act for New Zealand. Trusts \& Trustees, 25(9), 891-901.

Costa, A., \& Frankema, K. (2007). Trust and Control Interrelations: New Perspectives on the Trust - Control Nexus. Group \& Organization Management 32(4), 392-406. https://doi.org/I0.1I77//059601/06293871

Coughlan, T., (2020, December 01). Revenue Minister David Parker says trust tax rate could be raised if people use it to dodge new top income tax. Stuff. https://www.stuff.co.nz/national/politics/300172160/revenue-minister-david-parkersays-trust-tax-rate-could-be-raised-if-people-use-it-to-dodge-new-top-income-tax

Gibson Sheat, (2019). TRUSTS ACT 2019 Information for trustees. GibsonSheat. https://www.gibsonsheat.com/site/ gibsonsheat/Trusts\%20Act\%202019\%20-\%20information.pdf

Hawes, M. (2012). Family trusts: The must-have New Zealand guide. Random House.

Jayatilleke, S., \& Lai, R. (2018). A systematic review of requirements change management. Information and Software Technology, 93, $163-185$.

Kemps Weir. (2020, March 09). Trusts Act 2019: Documents to be kept by trustees. https://www.kempsweir.co.nz/news/trustsact-2019-documents-to-be-kept-by-trustees

Kenny, J., and Speight, K., (2020, November 10). The New Trusts Act: What does this mean for settlors, trustees, and beneficiaries? https://srblaw.co.nz/new-trusts-act

Law Commission. (April 2002). Some Problems in the Law of Trusts. https://www.lawcom.govt.nz/sites/default/files/ projectAvailableFormats/NZLC\%20R79.pdf

McLay, G. (2020). How to read New Zealand's new Trust Act 2019. 13 Journal of Equity, 325-436. http://dx.doi.org//0.2139/ ssrn. 3771008

McLeod, T. (2020a, April 18). Trust lawyer Tammy McLeod says a large proportion of Trusts are now likely not needed. She backgrounds their rise, their ensuing irrelevance, and identifies the remaining reasons a Trust might still be valuable. https://www.interest. co.nz/personal-finance// 04600/trust-lawer-tammy-mcleod-says-large-proportion-trusts-are-now-likely-not 
McLeod, T. (2020b, May 10). Trustees need to ensure they comply with the prudent investor rule and take steps to ensure the trust they manage is set up to avoid potential claims by beneficiaries, says trusts lawyer Tammy McLeod. https://www. interest.co.nz/personal-finance/l 04933/trustees-need-ensure-they-comply-prudent-investor-rule-and-take-steps-ensure.

Ministry of Justice. (2020, December 07). Trust law reform: A new Trusts Act for Aotearoa New Zealand. https://www.justice.govt. nz/justice-sector-policy/key-initiatives/trust-law-reform/

Te Puni Kōkiri. (2007). Ngā Manu Kōrihi / Communicating with Stakeholders. Te Puni Kōkiri. https://www.tpk.govt.nz/en/a-matoumohiotanga/governance/communicating-with-stakeholders

Norton, M. (2020, January 22). Will a property trust really protect you if a relationship sour? https://www.canstar.co.nz/homeloans/how-property-trusts-work-in-nz/

NZLAW. (2020). The trustees' role. Retrieved from https://nzlaw.co.nz/the-closing-chapter/the-trustees-role/

Parliamentary Counsel Office. (2019). Trusts Act 2019: Schedule I Transitional, Saving, and Related Provisions. http://www. legislation.govt.nz/act/public/2019/0038/latest/DLM7383135.html\#DLM7383152

Pearson, S. (2019, June). What's the ADKAR Model and How to Use It. https://tallyfy.com/adkar-model/

Powell, R., (2020, February 04). Whether and what to disclose, these are the questions. https://www.lawsociety.org.nz/news/ lawtalk/lawtalk-issue-936/whether-and-what-to-disclose-these-are-the-questions/

Quill. (2020, July 30). How to Set Up a Family Trust. https://www.quillgroup.com.au/wp-content/uploads/2020/07/How-to-setup-a-family-trust-structure-diagram.png

Speakman Law. (2020, May 21). Is your Trust Effective Against claims on You? https://staticl.squarespace.com/ static/583ce3b0e3df28/220a77d38/t/5ecc863db4f8delf779bf5dd/I5904620I4650/ls+your+Trust+Still+Effective+Aga inst+claims+on+you+-+21+May+2020.pdf

Stock, R. (2020, February 09). Top NZ lawyer closed his family trust and others should follow suit. Stuff. https://www.stuff. co.nz/business/1192669/3/top-lawyer-closed-his-family-trust-and-others-should-follow-suit

Walker, N., \& Shahbaz, F. (2020, August 21). Trustees - Information Retention and Disclosure. https://www.russellmcveagh.com/ insights/august-2020/trustees-information-retention-and-disclosure

Wang, Y., \& Li, H. (2019). Moral Leadership and Unethical Pro-organizational Behaviour: A Moderated Mediation Model. Front. Psychol., 10, 2640. doi:10.3389/fpsyg.2019.02640

Yu, R. (2002, July). Trust Resettlement: The Law and ATO's Statement of Principle. https://raymondyu.net/pub/papers/ TrustResettlement.pdf

Zaffron, S., \& Logan, D. (20II). The three laws of performance: Rewriting the future of your organization and your life (Vol. I70). John Wiley \& Sons. 